Research Article

\title{
Effect of plastic mulches on growth and yield of potato (Solanum tuberosum L.) in Dadeldhura, Nepal
}

\author{
Manoj Bhatta ${ }^{1 *}$, Bhimsen Shrestha ${ }^{1}$, Ananta Raj Devkota ${ }^{2}$, Khem Raj Joshi ${ }^{3}$, Sabin \\ Bhattarai $^{1}$ and Umisha Dhakal ${ }^{1}$ \\ ${ }^{1}$ Faculty of Agriculture, Agriculture and Forestry University, Rampur, Chitwan, Nepal \\ ${ }^{2}$ Department of Horticulture, Agriculture and Forestry University, Rampur, Chitwan, Nepal \\ ${ }^{3}$ PMAMP, Potato Super zone, Dadeldhura, Nepal \\ *Correspondence: arjunbhatta128@gmail.com \\ *ORCID: https://orcid.org/0000-0003-1654-040X
}

Received: July 20, 2020; Accepted: October 15, 2020; Published: October 30, 2020

(C) Copyright: Bhatta et al. (2020).

\begin{abstract}
(c) (1) (8)
This work is licensed under a Creative Commons Attribution-Non Commercial $\underline{4.0} \underline{\text { International License. }}$
\end{abstract}

\begin{abstract}
A field experiment was conducted from February to June, 2020 at Bhatkanda, Dadeldhura, Nepal to assess the effectiveness of plastic mulches in potato production. The experiment was laid out in Randomized Complete Block Design (RCBD) with four replications comprising of five treatments viz: T1: white plastic mulch (white on black colored), T2: silver plastic mulch (silver on black colored), T3: perforated black plastic mulch, T4: black plastic mulch and T5: control (without mulch). Results revealed that the black plastic mulch significantly increased the rate of emergence while perforated black plastic exhibited highest values of all other studied growth parameters, yield components and quality parameters. The highest marketable tuber yield was obtained in perforated black plastic $\left(6.05 \mathrm{~kg} / \mathrm{m}^{2}\right)$ followed by silver plastic $\left(5.62 \mathrm{~kg} / \mathrm{m}^{2}\right)$, white plastic $\left(5.46 \mathrm{~kg} / \mathrm{m}^{2}\right)$, black plastic $\left(5.14 \mathrm{~kg} / \mathrm{m}^{2}\right)$ and lowest marketable tuber yield was obtained in control condition $\left(4.07 \mathrm{~kg} / \mathrm{m}^{2}\right)$. Similarly, temperature difference between controlled and mulched condition at $15 \mathrm{~cm}$ depth of soil was observed up to $2.8^{\circ} \mathrm{C}$ with its highest value in black plastic mulch and lowest in control condition. The perforated black plastic mulch was found most economical with maximum value of net return (NRs. 1904.31 thousands/ha) and B: C ratio (5.83). This study concludes that the use of perforated black plastic mulch is most economical with optimum plant growth and yield, producing best quality potatoes under climatic condition of Dadeldhura, Nepal.
\end{abstract}

Keywords: Plastic mulching, potato, perforated black plastic mulch, yield

Correct citation: Bhatta, M., Shrestha, B., Devkota, A. R., Joshi, K. R., Bhattarai, S., \& Dhakal, U. (2020). Effect of plastic mulches on growth and yield of potato (Solanum tuberosum L.) in Dadeldhura, Nepal. Journal of Agriculture and Natural Resources, 3(2), 228-240. DOI: https://doi.org/10.3126/janr.v3i2.32509

\section{INTRODUCTION}

Potato (Solanum tuberosum L.), belonging to Solanaceae family is one of the most important vegetable crops having a balanced diet. It is commercial non-cereal produce of Nepal and an important source of income for the farmers (Upadhyay et al., 2020). It is used as subsidiary food as part of vegetables in Terai region, whereas as staple food in Hill and Mountain Regions of Nepal (Subedi et al., 2019). It contains water 75 to 80\%, carbohydrates 16 to $20 \%$, crude protein 2.5 to $3.2 \%$, true protein 1.2 to $2.2 \%$, mineral matter 0.8 to $1.2 \%$, 
Journal of Agriculture and Natural Resources (2020) 3(2): 228-240

ISSN: 2661-6270 (Print), ISSN: 2661-6289 (Online)

DOI: https://doi.org/10.3126/janr.v3i2.32509

crude fats 0.1 to $0.2 \%$, crude fiber $0.6 \%$ and different vitamins (Reddy et al., 2018). Being cool season crop, potato grows well in certain areas having cool climatic regime but the sprout development rate depends on temperature of soil (Samy \& EI-Zohiri, 2013). The optimum temperature of soil for initiating tubers is $16-19^{\circ} \mathrm{C}$ (Khan et al., 2011). Development of tuber decreases as soil temperatures increases above $20^{\circ} \mathrm{C}$ and growth of tuber practically stops at soil temperatures above $30^{\circ} \mathrm{C}$ (Samy \& EI-Zohiri, 2013). The reason for its potentiality and wider adaptability to grow year-round, its importance is constantly increasing.

Potato is the major cash crop of Nepal that ranks fifth in terms of area coverage (193,997 ha), second in quantity of production $(3,112,947 \mathrm{t})$ and first in productivity $\left(16.05 \mathrm{t} \mathrm{ha}^{-1}\right)$ as compared with that of main staple food crops rice, maize, wheat and finger millet (MoALD, 2019). It accounts for about 6.57 and $2.17 \%$ of Agricultural Gross Domestic Product (AGDP) and Gross Domestic Product (GDP) of nation respectively (Gairhe et al., 2017). Nepal is one of the top twenty countries where potato contributes substantially for human diet (Subedi et al., 2019). Province 1 constitutes the highest production volume of $30.44 \%$ of national production with the highest productivity of $17.92 \mathrm{t} \mathrm{ha}^{-1}$ in Bagmati province (MoALD, 2018/19). In Dadeldhura district, potato is cultivated in 1,154 ha area producing 16,169 t with average productivity of $14.01 \mathrm{t} \mathrm{ha}^{-1}$, which is lower than both attainable yield and national average (16.05 t ha-1) (MoALD, 2019).

Mulching is one of the improved cultivation practices to increase yield and productivity of potato to its maximum. According to Singh and Ahmed (2008), mulching shows significant influence on growth and yield of potato. Mulching promotes soil water infiltration and crop water availability which helps to improve soil biodiversity and environmental benefits (Memon et al., 2017). Mulches function as cover crop and reduce tillage operations that have some ecological advantages over conventional land preparation tasks causing minimum alterations in soil environment (Ahmed et al., 2017). This contributes to higher water use efficiency by plants, higher yields and greater economic benefit. Mulching with black plastic film increases tuber yield by $16 \%$ as compared to no mulch (Kang et al., 2003). Bharati et al. (2020) also reported enhanced emergence, plant height and number of stems of potato increases with black plastic mulching. Orzolek et al. (1993) reported that increased soil temperature especially during early spring by polyethene mulch helps to reduce weed population as well as reduces insect pest's population favoring higher crop yield and efficient use of soil nutrients. Mulching cut off crop irrigation requirement by reducing the rate of soil water evaporation up to $50 \%$ (Hatfield, 2001).

Farmers of the study area are facing the problem of irrigation water due to scarce water resources. Limited water available for plant is lost due to evaporation from soil surface due to lack of suitable cultivation practices like mulching. In absence of mulching practices, nutrient runoff takes place from bare soil surface due to excessive rainfall and results in loss of mineral nutrients which are vital for plant growth and development. Weed and pest problem on other hand causes substantial loss in yield and quality of crop contributing to lower yield of potato. Due to all these, current productivity of potato in Dadeldhura district is unable to meet the ever-increasing demand of potato in the market. To overcome this, improvement of cultivation practices like mulching is easiest and best option. Mulching technique being an important step towards higher agricultural production and sustainable use of resources, it's vital to consider the use of proper mulching materials that are beneficial to soil and its biodiversity. According to NRCS (2012), use of properly undecomposed and different 
Journal of Agriculture and Natural Resources (2020) 3(2): 228-240

ISSN: 2661-6270 (Print), ISSN: 2661-6289 (Online)

DOI: https://doi.org/10.3126/janr.v3i2.32509

organic mulch materials without considerations of their $\mathrm{C}: \mathrm{N}$ ratio results in nutrients immobilization in soil that hinders plant growth and development. Field trials performed in Dadeldhura district by Joshi et al. (2020) and Bharati et al. (2020) have proved plastic mulching as the best mulching material for potato cultivation. But there is still a research gap in finding the best and effective plastic mulch among various plastic mulches available in the market. So, the research was conducted to find out best and effective type of plastic mulch assessing the effect of different types of plastic mulches on growth and yield of potato and on its soil environment.

\section{MATERIALS AND METHODS}

\section{Experimental site}

The experiment was carried out in farmer's field at Bhatkanda -1, Dadeldhura, Province no.7, Nepal. It is situated in the humid sub-tropical region having elevation 1,745masl. The site is located in mid hills at $29^{\circ} 14^{\prime} 57.32^{\prime \prime} \mathrm{N}$ latitude and $80^{\circ} 38^{\prime} 2.06^{\prime}$ ' E longitude.

\section{Climatic condition during experimentation}

The meteorological data for cropping season were taken from the regional department of hydrology and meteorological station, Dadeldhura from February ( $3^{\text {rd }}$ week) to June $\left(4^{\text {th }}\right.$ week) in 2020. The average maximum temperature was observed $25.8^{\circ} \mathrm{C}$ which ranged from $17.8^{\circ} \mathrm{C}$ to $31.8^{\circ} \mathrm{C}$ whereas the average minimum temperature was observed $12.5^{\circ} \mathrm{C}$ which ranged from $6.2^{\circ} \mathrm{C}$ to $19^{\circ} \mathrm{C}$. The total rainfall and average humidity during the experimentation were $86.7 \mathrm{~mm}$ and $56.6 \%$ respectively.

\section{Crop Management}

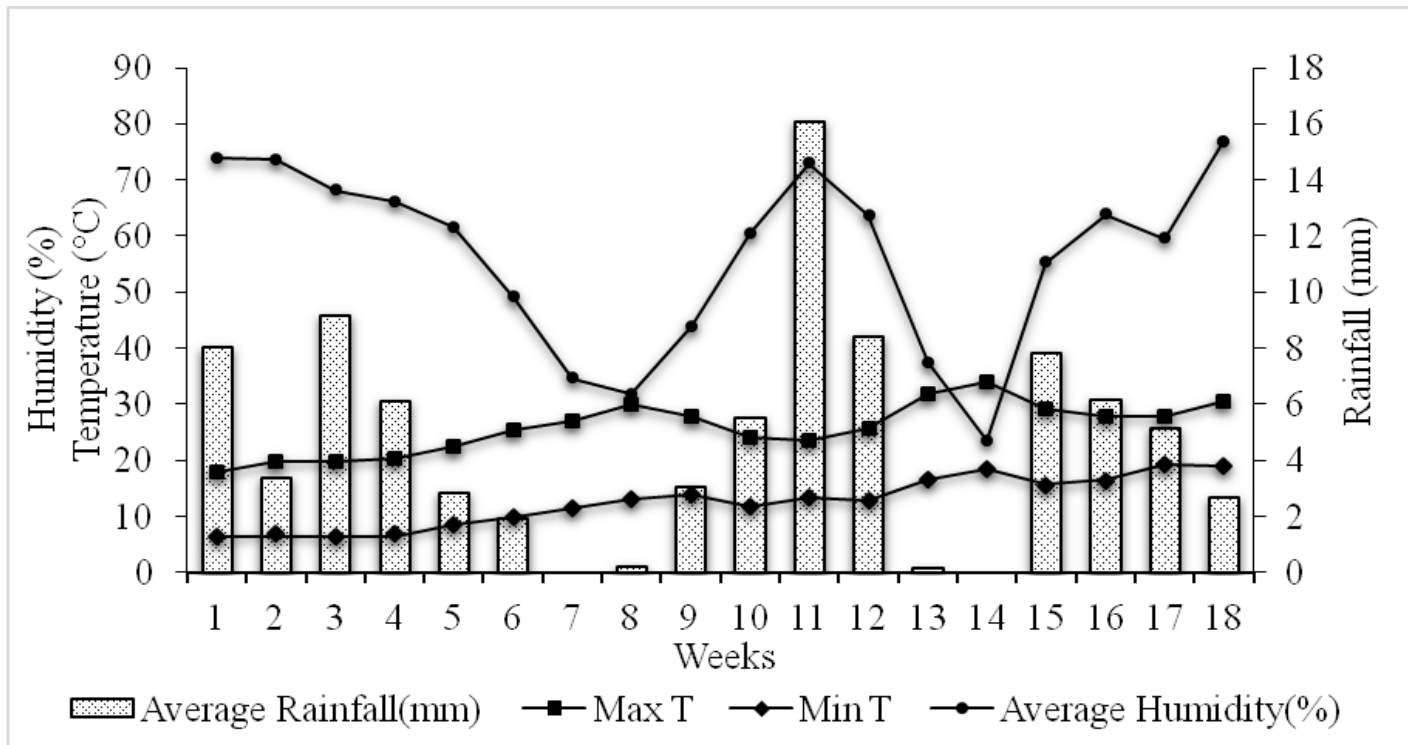

Figure 1: Weather condition during experimentation period in Dadeldhura in 2020

Finely graded medium sized seed tubers (40-50 gm per seed tuber) of Desiree variety of potato were sown on $25^{\text {th }}$ February, 2020 with $60 * 25 \mathrm{~cm}$ spacing. Before sowing, one deep plowing and 3 light plowing followed by harrowing was done for field preparation. The recommended dose of fertilizers for Desiree variety of potato FYM @20 ton/ha, N: $\mathrm{P}_{2} \mathrm{O}_{5}$ : $\mathrm{K}_{2} \mathrm{O} @ 140: 220: 100 \mathrm{~kg} / \mathrm{ha}$ were applied. All the above-mentioned fertilizer doses were 
Journal of Agriculture and Natural Resources (2020) 3(2): 228-240

ISSN: 2661-6270 (Print), ISSN: 2661-6289 (Online)

DOI: https://doi.org/10.3126/janr.v3i2.32509

incorporated into the field before sowing. Due to mulches on the field, full dose of nitrogen was given as the basal dose at the time of sowing.

\section{Experimental Design}

The experiment was laid out in Randomized Complete Block Design (RCBD) with 4 replications and five treatments viz:

$\mathrm{T}_{1}=$ White Plastic Mulching (White on black colored plastic)

$\mathrm{T}_{2}=$ Silver Plastic Mulching (Silver on black colored plastic)

$\mathrm{T}_{3}=$ Perforated Black Plastic Mulching (Uniform perforations made on plastic film by sack needle of $3 \mathrm{~mm}$ diameter)

$\mathrm{T}_{4}=$ Black Plastic Mulching

$\mathrm{T}_{5}=$ Control (without mulch)

The individual plot size was $3.6 \times 1 \mathrm{~m}^{2}$ with 6 rows per plot and 4 plants per row.

\section{Data collection}

Randomly selected 5 plants from each plot excluding border plants were used to measure various growth and yield parameters. Data regarding economics were taken and calculated using standard technique.

\section{Statistical analysis}

ANOVA was computed and the means were compared by using Duncan's multiple Range Test (DMRT) at 5\% level of significance (Gomez \& Gomez, 1984; Shrestha, 2019).

\section{RESULTS AND DISCUSSION}

\section{Effect of plastic mulches on plant growth parameters}

Days to $90 \%$ emergence, $50 \%$ flowering and $90 \%$ physiological maturity were significantly influenced by plastic mulching (Table 1). Black plastic took lowest number of day for attaining $90 \%$ emergence followed by perforated black plastic. Similarly, days for 50\% flowering and $90 \%$ maturity were lowest in perforated black plastic which was statistically similar with black plastic mulch for 50\% flowering. Whereas, the highest days for $90 \%$ emergence, $50 \%$ flowering and $90 \%$ physiological maturity were observed in control condition. These results are in accordance with those of Ping, Xuejun, \& Xing (1994) and Mahmood M. M., Farooq, Hussain, \& Sher (2002). The quicker germination, flowering and physiological maturity in mulched condition was due to increase in soil temperature by use of different plastic mulches. Black polyethylene mulch can increase soil temperature up to 9degree Celsius which stimulates quicker germination (Kumari, 2012). According to Azad (2015), mulching reduces the day to harvest because of earlier physiological maturity in mulched condition.

An appraisal of data (Table 2) revealed that the maximum plant height of potato was measured in black plastic $(21.49 \mathrm{~cm})$ at 45 DAP which was statistically similar with perforated black plastic and silver plastic. However, maximum plant height of $38.89 \mathrm{~cm}$ was recorded in perforated black plastic mulch at $60 \mathrm{DAP}$, which was statistically at par with silver plastic and black plastic. Significantly minimum plant height was recorded in control plot as there was no any mulch used. Ahmed, Mahmud, Hossain, Zaman, and Halder (2017) also reported higher plant height of potato in black polythene mulch over white polythene. The higher plant height in perforated black plastic mulch might be due to the reason that perforations over the plastic film allows air to pass through it and hence increases oxygen 
Journal of Agriculture and Natural Resources (2020) 3(2): 228-240

ISSN: 2661-6270 (Print), ISSN: 2661-6289 (Online)

DOI: https://doi.org/10.3126/janr.v3i2.32509

availability around root zone of plant contributing to better growth of shoot. Plastic mulches contribute to better availability of soil moisture and optimum soil temperature for better plant growth and development.

Table 1: Days to $90 \%$ emergence, $50 \%$ flowering and $90 \%$ physiological maturity (Haulm senescence) of potato plant as influenced by plastic mulches at Dadeldhura, Nepal in 2020

\begin{tabular}{|c|c|c|c|}
\hline Treatments & $\begin{array}{c}\text { Days to } 90 \% \\
\text { Emergence }\end{array}$ & $\begin{array}{c}\text { Days to } 50 \% \\
\text { Flowering } \\
\end{array}$ & $\begin{array}{c}\text { Days to } 90 \% \\
\text { Physiological maturity }\end{array}$ \\
\hline White plastic & $37.50^{\mathrm{d}}$ & $75.00^{\mathrm{c}}$ & $100.75^{\mathrm{c}}$ \\
\hline Silver plastic & $34.75^{\mathrm{c}}$ & $74.00^{\mathrm{b}}$ & $100.00^{\mathrm{bc}}$ \\
\hline Perforated black plastic & $30.75^{\mathrm{b}}$ & $70.50^{\mathrm{a}}$ & $98.50^{\mathrm{a}}$ \\
\hline Black plastic & $29.50^{\mathrm{a}}$ & $70.75^{\mathrm{a}}$ & $99.00^{\mathrm{ab}}$ \\
\hline Control & $40.75^{\mathrm{e}}$ & $76.50^{\mathrm{d}}$ & $101.25^{\mathrm{c}}$ \\
\hline F-test & $* *$ & $* *$ & $* *$ \\
\hline $\operatorname{LSD}(0.05)$ & 0.81 & 0.813 & 1.25 \\
\hline $\operatorname{SEm}( \pm)$ & 0.26 & 0.30 & 0.41 \\
\hline $\mathrm{CV}, \%$ & 1.51 & 0.72 & 0.81 \\
\hline Grand Mean & 34.65 & 73.35 & 99.90 \\
\hline
\end{tabular}

Table 2: Plant height (cm) of potato as influenced by using different types of plastic mulches at Dadeldhura, Nepal in 2020.

\begin{tabular}{lccc}
\hline & & Plant height $(\mathrm{cm})$ & \\
\cline { 2 - 4 } Treatments & $45 \mathrm{DAP}$ & $60 \mathrm{DAP}$ & 59.28 \\
\hline White plastic & $16.17^{\mathrm{b}}$ & $33.16^{\mathrm{bc}}$ & 61.55 \\
Silver plastic & $20.33^{\mathrm{a}}$ & $37.39^{\mathrm{ab}}$ & 64.46 \\
Perforated black plastic & $20.4^{\mathrm{a}}$ & $38.89^{\mathrm{a}}$ & 60.10 \\
Black plastic & $21.49^{\mathrm{a}}$ & $37.33^{\mathrm{ab}}$ & 55.20 \\
Control & $12.15^{\mathrm{c}}$ & $29.17^{\mathrm{c}}$ & $\mathrm{ns}$ \\
\hline F-test & $* *$ & $* *$ & $\mathrm{~ns}$ \\
LSD $(0.05)$ & 2.56 & 5.06 & 2.8 \\
SEm $( \pm)$ & 0.83 & 1.64 & 9.29 \\
CV, $\%$ & 9.15 & 9.33 & 60.118 \\
\hline Grand Mean & 18.107 & 35.19 & $\mathrm{~s}$ \\
\hline
\end{tabular}

$D A P=$ Days after planting, Means followed by the same letter(s) in a column are not significantly different by DMRT at 5\% level of significance. $n s=$ Non-significant, $*=$ significant at $5 \%$ probability level, $* *=$ significant at $1 \%$ probability level

Number of leaves of plants per hill was found to be statistically superior in plastic mulches as compared to control plots (Table 3). However, among different plastic mulches, the number of leaves per hill was found comparable with each other except at 45 DAP, when white plastic mulch resulted lower number of leaves per hill (39) than other plastic mulches. Maximum number of leaves per hill was recorded in black plastic (77) at 45 DAP and in perforated black plastic at 60 DAP (268) and 75 DAP (427). Nitrogen and phosphorus content as well as nutrient uptake is significantly higher in mulched plots as compared to that of un-mulched plots which is necessary for proper vegetative growth of plant (Hundal et al., 2000). The number of main stems per hill were found insignificant among the treatments. 
Journal of Agriculture and Natural Resources (2020) 3(2): 228-240

ISSN: 2661-6270 (Print), ISSN: 2661-6289 (Online)

DOI: https://doi.org/10.3126/janr.v3i2.32509

Table 3: Number of leaves of potato plants as influenced by using different types of plastic mulches at Dadeldhura, Nepal in 2020.

\begin{tabular}{|c|c|c|c|}
\hline \multirow{2}{*}{ Treatments } & \multicolumn{3}{|c|}{ Average number of leaves per hill } \\
\hline & 45DAP & 60DAP & 75DAP \\
\hline White plastic & $39.65^{\mathrm{b}}$ & $201.75^{\mathrm{ab}}$ & $362.15^{\mathrm{a}}$ \\
\hline Silver plastic & $72.80^{\mathrm{a}}$ & $262.55^{\mathrm{a}}$ & $394.70^{\mathrm{a}}$ \\
\hline Perforated black plastic & $66.25^{\mathrm{a}}$ & $268.55^{\mathrm{a}}$ & $427.40^{\mathrm{a}}$ \\
\hline Black plastic & $77.45^{\mathrm{a}}$ & $256.45^{\mathrm{a}}$ & $362.00^{\mathrm{a}}$ \\
\hline Control & $34.35^{\mathrm{b}}$ & $132.95^{\mathrm{b}}$ & $229.45^{\mathrm{b}}$ \\
\hline F-test & $* *$ & $* *$ & $*$ \\
\hline $\operatorname{LSD}(0.05)$ & 24.61 & 74.42 & 109.26 \\
\hline $\operatorname{SEm}( \pm)$ & 7.99 & 24.15 & 35.46 \\
\hline $\mathrm{CV}, \%$ & 27.5 & 21.52 & 19.97 \\
\hline Grand Mean & 58.1 & 224.45 & 355.14 \\
\hline
\end{tabular}

Plastic mulches had insignificant effect on stem diameter at 60 DAP but had significant effect at 75 DAP (Table 4). At 75DAP stem diameter was observed highest in perforated black plastic $(15.3 \mathrm{~mm})$ which was significantly at par with silver plastic $(14.45 \mathrm{~mm})$ and white plastic $(14.33 \mathrm{~mm})$. Plastic mulching results in lower weed population enhancing nutrient availability to the plants as well as optimizes the soil temperature for crop growth and development. Perforated pores over plastic films provides aeriation in root zone of plant and hence contribute to better growth and development of plant. The lowest value of stem diameter was observed in control condition (12.24).

Table 4: Stem diameter $(\mathrm{mm})$ of potato plants as influenced by using different types of plastic mulching as treatment at Dadeldhura, Nepal in 2020.

\begin{tabular}{lcc}
\hline \multirow{2}{*}{ Treatments } & \multicolumn{2}{c}{ Stem diameter $(\mathrm{mm})$} \\
\cline { 2 - 3 } & $60 \mathrm{DAP}$ & $75 \mathrm{DAP}$ \\
\hline White plastic & 11.47 & $14.33^{\mathrm{ab}}$ \\
Silver plastic & 11.88 & $14.45^{\mathrm{ab}}$ \\
Perforated black plastic & 12.58 & $15.30^{\mathrm{a}}$ \\
Black plastic & 11.98 & $13.46^{\mathrm{bc}}$ \\
Control & 10.94 & $12.24^{\mathrm{c}}$ \\
\hline F-test & $\mathrm{ns}$ & $* *$ \\
LSD $(0.05)$ & 2.54 & 1.43 \\
SEm $( \pm)$ & 0.37 & 0.47 \\
CV, $\%$ & 6.23 & 6.70 \\
\hline Grand Mean & 11.80 & 13.96 \\
\hline
\end{tabular}

Means followed by the same letter(s) in a column are not significantly different by DMRT at 5\% level of significance. $n s=$ Non-significant, $*=$ significant at $5 \%$ probability level, $* *=$ significant at $1 \%$ probability level, DAP = Days after planting

Note: stem diameter was measured using calibrated Vernier Caliper

\section{Effect of plastic mulches on yield and yield parameters}

Significantly maximum number of tubers per hill (10.10) and average tuber yield per hill $(925.20 \mathrm{~g})$ were found in perforated black plastic mulch (Table 5). It was observed that perforated black plastic mulch, white plastic, silver plastic and black plastic had $36.49 \%$, $23 \%, 12.2 \%$ and $7.43 \%$ higher numbers of tubers per hill than control condition. Whereas, 
Journal of Agriculture and Natural Resources (2020) 3(2): 228-240

ISSN: 2661-6270 (Print), ISSN: 2661-6289 (Online)

DOI: https://doi.org/10.3126/janr.v3i2.32509

average tuber weight was found maximum in black plastic mulch (107.13g) which was statistically similar with other plastic mulches. The minimum average tuber weight was recorded in control condition $(61.7 \mathrm{~g})$.

Table 5: Average number of tubers per hill, average tuber yield per hill (g) and average weight of individual tuber (Average tuber yield per hill/average tuber number per hill) of potato plants as influenced by different plastic mulches at Dadeldhura, Nepal in 2020.

\begin{tabular}{|c|c|c|c|}
\hline Treatments & $\begin{array}{l}\text { Average number of } \\
\text { tubers per hill }\end{array}$ & $\begin{array}{l}\text { Average tuber yield per } \\
\text { hill }(\mathrm{g})\end{array}$ & Average tuber weight $(g)$ \\
\hline White plastic & $9.10^{\mathrm{ab}}$ & $793.20^{\mathrm{a}}$ & $89.26^{\mathrm{a}}$ \\
\hline Silver plastic & $8.30^{\mathrm{b}}$ & $879.50^{\mathrm{a}}$ & $105.55^{\mathrm{a}}$ \\
\hline Perforated black plastic & $10.10^{\mathrm{a}}$ & $925.20^{\mathrm{a}}$ & $92.60^{\mathrm{a}}$ \\
\hline Black plastic & $7.95^{b}$ & $844.80^{\mathrm{a}}$ & $107.13^{\mathrm{a}}$ \\
\hline Control & $7.40^{\mathrm{b}}$ & $452.50^{\mathrm{b}}$ & $61.70^{\mathrm{b}}$ \\
\hline F-test & $*$ & $* *$ & $* *$ \\
\hline $\operatorname{LSD}(0.05)$ & 1.70 & 151.00 & 18.91 \\
\hline $\operatorname{SEm}( \pm)$ & 0.60 & 49.00 & 6.14 \\
\hline $\mathrm{CV}, \%$ & 12.84 & 12.60 & 13.45 \\
\hline Grand Mean & 8.57 & 779.04 & 91.24 \\
\hline
\end{tabular}

Highly significant difference was found in marketable tuber number, unmarketable tuber number and total tuber number per meter square in mulched condition as compared to without mulch (Table 6). Significantly maximum marketable tuber number per $\mathrm{m}^{2}$ was observed in perforated black plastic mulch (67) which was statistically similar with white plastic (65). Whereas the lowest number of marketable seed tuber per $\mathrm{m}^{2}$ was found in control condition (40). Similarly, maximum unmarketable tuber number per $\mathrm{m}^{2}$ (15) was recorded in control plots. The total tuber number per meter square was found significantly maximum in perforated black plastic mulch (71) followed by white plastic (68), black plastic (64), silver plastic (63) and Control (56). Tuber number was observed highest in mulch condition than that of un-mulched as mulching help to regulate the temperature, maintain proper environmental condition which is in accordance with the finding of (Hochmuth, 2018). Kadar, Senge, Mojid, \& Onishi, (2017) also recorded higher marketable seed tuber number and total tuber number per square meter in perforated black plastic.

Tuber yield of potato was significantly influenced by the treatments (Table 7). The marketable tuber yield was observed significantly higher in perforated black plastic mulch $\left(6.05 \mathrm{~kg} / \mathrm{m}^{2}\right)$ which was statistically similar to silver plastic mulch $\left(5.62 \mathrm{~kg} / \mathrm{m}^{2}\right)$ and white plastic mulch $\left(5.46 \mathrm{~kg} / \mathrm{m}^{2}\right)$. The unmarketable tuber yield was recorded maximum in control condition $\left(80 \mathrm{~g} / \mathrm{m}^{2}\right)$ and minimum in silver plastic $\left(50 \mathrm{~g} / \mathrm{m}^{2}\right)$. Significantly maximum total tuber yield was obtained in perforated black plastic mulch $\left(6.08 \mathrm{~kg} / \mathrm{m}^{2}\right)$ followed by silver plastic $\left(5.67 \mathrm{~kg} / \mathrm{m}^{2}\right)$, white plastic $\left(5.49 \mathrm{~kg} / \mathrm{m}^{2}\right)$ and black plastic $\left(5.17 \mathrm{~kg} / \mathrm{m}^{2}\right)$. The minimum total tuber yield was obtained in control plots $\left(4.15 \mathrm{~kg} / \mathrm{m}^{2}\right)$. Generally, higher yield in plastic mulches is accompanied with the lower weed incidence, lower insect pest damage and reduced soil water evaporation (Orzolek et al., 1993). However, non- perforated plastic mulching reduces the effective rainfall by preventing infiltration, but in case of perforated plastic mulching, effective rainfall is increased by $9 \%$ through enhanced infiltration, both type of plastic controlling the soil temperature (Kadar et al.,2017). Thus, the results are in 
Journal of Agriculture and Natural Resources (2020) 3(2): 228-240

ISSN: 2661-6270 (Print), ISSN: 2661-6289 (Online)

DOI: https://doi.org/10.3126/janr.v3i2.32509

accordance with the findings of Kadar et al. (2017) that they also observed the highest seed yield of soybean in perforated plastic mulch. They explained the reason behind this was due to effective utilization of rain water by increasing moisture extraction ratio in deeper layers of soil that helped to increase total readily available soil moisture for plant growth and yield. In addition, perforations made over plastic film helps in aeriation of root zone and evaporation of excess water around the plants thereby enhancing the growth of tuber. Comparatively lesser yield in black plastic than other plastic mulches might be due to excessive rainfall and higher temperature during tuberization and tuber growth (Figure 1). Kapoor (2012) also reported that silver and white coloured plastic mulches proved superior in tuber yield of potato than black colored plastic mulch.

Table 6: Marketable seed tuber number (Healthy tubers of diameter $>25 \mathrm{~mm}$ ), Unmarketable tuber number (Undersized tubers with diameter $<25 \mathrm{~mm}$, diseased, deformed and insect attacked) and Total tuber number per square meter of potato as influenced by different plastic mulches at Dadeldhura, Nepal in 2020.

\begin{tabular}{|c|c|c|c|}
\hline Treatments & $\begin{array}{c}\text { Marketable tuber } \\
\text { number } / \mathrm{m}^{2}\end{array}$ & $\begin{array}{c}\text { Unmarketable tuber } \\
\text { number/m} / \mathrm{m}^{2}\end{array}$ & $\begin{array}{r}\text { Total tuber } \\
\text { number } / \mathrm{m}^{2}\end{array}$ \\
\hline White plastic & $65.75^{\mathrm{a}}$ & $2.50^{\mathrm{b}}$ & $68.25^{\mathrm{ab}}$ \\
\hline Silver plastic & $57.75^{\mathrm{b}}$ & $5.25^{\mathrm{b}}$ & $63.00^{\mathrm{b}}$ \\
\hline Perforated black plastic & $67.50^{\mathrm{a}}$ & $4.25^{\mathrm{b}}$ & $71.75^{\mathrm{a}}$ \\
\hline Black plastic & $61.00^{\mathrm{ab}}$ & $3.50^{\mathrm{b}}$ & $64.50^{\mathrm{b}}$ \\
\hline Control & $40.25^{\mathrm{c}}$ & $15.75^{\mathrm{a}}$ & $56.00^{c}$ \\
\hline F-test & ** & *** & ** \\
\hline $\operatorname{LSD}(0.05)$ & 6.27 & 2.86 & 5.88 \\
\hline $\operatorname{SEm}( \pm)$ & 2.04 & 0.93 & 1.91 \\
\hline $\mathrm{CV}, \%$ & 6.96 & 29.70 & 5.9 \\
\hline Grand Mean & 58.45 & 6.25 & 64.7 \\
\hline
\end{tabular}

The number of under sized tubers and small sized tubers per $\mathrm{m}^{2}$ were found significantly higher in control condition (11 and 21) but found statistically indifferent among different plastic mulches (Table 8). Highest number of medium sized tubers per $\mathrm{m}^{2}$ were observed in white plastic mulch (49) which was statistically at par with perforated black plastic mulch (45). The lowest number of medium sized tubers was observed in control condition (34). Whereas, the number of large sized tubers were found significantly higher in all plastic mulches than in control plot. The higher number of medium sized tubers in white plastic mulch and large sized tubers in silver plastic mulch was due to the light that is reflected from white and silver plastic mulches which results in deposition of more photosynthate into the tubers (Matheny, 1992). Higher number of large sized tubers in black plastic was due to raised soil temperature by black plastic, less weed competition, better nutrient uptake, and better soil moisture regimes (Luis et al., 2011). Higher number of medium and large sized tubers in perforated black mulch was due to better moisture availability, proper aeration along with optimal temperature in root zone of plant (Kadar et al., 2017). 
Journal of Agriculture and Natural Resources (2020) 3(2): 228-240

ISSN: 2661-6270 (Print), ISSN: 2661-6289 (Online)

DOI: https://doi.org/10.3126/janr.v3i2.32509

Table 7: Marketable seed tuber yield (Healthy tubers of diameter $>25 \mathrm{~mm}$ ), Unmarketable tuber yield (Undersized tubers having diameter $<25 \mathrm{~mm}$, diseased, deformed and insect attacked) and Total tuber yield in kg per square meter of potato plants as influenced by different types of plastic mulches at Dadeldhura, Nepal in 2020.

\begin{tabular}{lccc}
\hline Treatments & $\begin{array}{c}\text { Marketable tuber } \\
\text { yield }\left(\mathrm{kg} / \mathrm{m}^{2}\right)\end{array}$ & $\begin{array}{c}\text { Unmarketable tuber } \\
\text { yield }\left(\mathrm{kg} / \mathrm{m}^{2}\right)\end{array}$ & $\begin{array}{c}\text { Total tuber yield } \\
\left(\mathrm{kg} / \mathrm{m}^{2}\right)\end{array}$ \\
\hline White plastic & $5.46^{\mathrm{ab}}$ & $0.02^{\mathrm{b}}$ & $5.48^{\mathrm{ab}}$ \\
Silver plastic & $5.62^{\mathrm{ab}}$ & $0.05^{\mathrm{b}}$ & $5.67^{\mathrm{ab}}$ \\
Perforated black plastic & $6.05^{\mathrm{a}}$ & $0.03^{\mathrm{b}}$ & $6.08^{\mathrm{a}}$ \\
Black plastic & $5.14^{\mathrm{b}}$ & $0.03^{\mathrm{b}}$ & $5.17^{\mathrm{b}}$ \\
Control & $4.07^{\mathrm{b}}$ & $0.08^{\mathrm{a}}$ & $4.15^{\mathrm{c}}$ \\
\hline F-test & $* *$ & $* *$ & $* *$ \\
$\mathrm{LSD}(0.05)$ & 0.81 & 0.02 & 0.80 \\
$\mathrm{SEm}( \pm)$ & 0.26 & 0.01 & 0.26 \\
$\mathrm{CV}, \%$ & 10.00 & 38.61 & 9.83 \\
\hline Grand Mean & 5.27 & 0.04 & 5.31 \\
\hline Means followed by the same letter $(s)$ in a column are not significantly different by DMRT at $5 \%$ level of \\
significance. ns $=$ Non-significant, $*=$ significant at $5 \%$ probability level, $* *=$ significant at 1\% probability level
\end{tabular}

Table 8: Grades of harvested potato tubers on the basis of size as influenced by different plastic mulches at Dadeldhura, Nepal in 2020

\begin{tabular}{|c|c|c|c|c|}
\hline Treatments & $\begin{array}{c}\text { Undersized } \\
\text { tubers } / \mathrm{m}^{2} \\
(<25 \mathrm{~mm})\end{array}$ & $\begin{array}{l}\text { Small sized } \\
\text { tubers } / \mathrm{m}^{2} \\
(25-35 \mathrm{~mm})\end{array}$ & $\begin{array}{c}\text { Medium sized } \\
\text { tubers } / \mathrm{m}^{2} \\
(35-55 \mathrm{~mm})\end{array}$ & $\begin{array}{c}\text { Large sized } \\
\text { tubers } / \mathrm{m}^{2} \\
(>55 \mathrm{~mm})\end{array}$ \\
\hline White plastic & $2.50^{\mathrm{b}}$ & $9.25^{\mathrm{b}}$ & $49.00^{\mathrm{a}}$ & $6.25^{\mathrm{a}}$ \\
\hline Silver plastic & $5.75^{b}$ & $9.00^{\mathrm{b}}$ & $39.00^{c}$ & $7.25^{\mathrm{a}}$ \\
\hline Perforated black plastic & $3.75^{b}$ & $7.25^{\mathrm{b}}$ & $45.75^{\mathrm{ab}}$ & $8.50^{\mathrm{a}}$ \\
\hline Black plastic & $3.25^{\mathrm{b}}$ & $7.25^{b}$ & $40.75^{\mathrm{bc}}$ & $7.25^{\mathrm{a}}$ \\
\hline Control & $11.00^{\mathrm{a}}$ & $21.75^{\mathrm{a}}$ & $34.75^{\mathrm{c}}$ & $1.00^{\mathrm{b}}$ \\
\hline F-test & $* *$ & $* *$ & $* *$ & $* *$ \\
\hline $\operatorname{LSD}(0.05)$ & 3.30 & 5.06 & 6.11 & 3.7 \\
\hline $\operatorname{SEm}( \pm)$ & 1.06 & 1.64 & 1.98 & 1.19 \\
\hline $\mathrm{CV}, \%$ & 40.22 & 30.10 & 9.50 & 39.32 \\
\hline Grand Mean & 5.25 & 10.90 & 41.85 & 6.05 \\
\hline
\end{tabular}

\section{Soil temperature}

Average soil temperature at $15 \mathrm{~cm}$ depth during the experimental period was significantly affected by different plastic mulches (Table). Results indicated that soil temperature at $15 \mathrm{~cm}$ depth was significantly higher in black plastic mulch at first $\left(17.61^{\circ} \mathrm{C}\right)$, second $\left(18.51^{\circ} \mathrm{C}\right)$ and third month $\left(19.84^{\circ} \mathrm{C}\right)$ of planting. Lowest value of soil temperature was observed in control condition $\left(15.63^{\circ} \mathrm{C}, 15.76^{\circ} \mathrm{C}, 18.24^{\circ} \mathrm{C}\right)$ at first, second and third month of planting respectively. And soil temperature of other treatments lied between them. The lower soil temperature in white and silver plastic than black plastic was due to the higher reflection of light radiation by white and silver plastic mulch that prevents higher temperature buildup under plastic and in the root zone of plant (Manganelli, 2017). Lower temperature in perforated black plastic mulch than black plastic might be due to aeration through perforations made over plastic film. 
Journal of Agriculture and Natural Resources (2020) 3(2): 228-240

ISSN: 2661-6270 (Print), ISSN: 2661-6289 (Online)

DOI: https://doi.org/10.3126/janr.v3i2.32509

Table 9: Soil temperature (in degree Celsius) as influenced by plastic mulches at Dadeldhura, Nepal in 2020.

\begin{tabular}{|c|c|c|c|}
\hline Treatments & $\begin{array}{l}\text { Soil temperature } \\
\text { in first month } \\
\text { of planting }\left({ }^{\circ} \mathrm{C}\right)\end{array}$ & $\begin{array}{l}\text { Soil temperature } \\
\text { in second month } \\
\text { of planting }\left({ }^{\circ} \mathrm{C}\right)\end{array}$ & $\begin{array}{l}\text { Soil temperature } \\
\text { in third month } \\
\text { of planting }\left({ }^{\circ} \mathrm{C}\right)\end{array}$ \\
\hline White plastic & $15.75^{\mathrm{c}}$ & $17.49^{\mathrm{c}}$ & $18.84^{\mathrm{c}}$ \\
\hline Silver plastic & $16.62^{\mathrm{b}}$ & $17.09^{\mathrm{d}}$ & $19.60^{\mathrm{b}}$ \\
\hline Perforated black plastic & $16.85^{\mathrm{b}}$ & $17.743^{\mathrm{b}}$ & $19.69^{\mathrm{b}}$ \\
\hline Black plastic & $17.61^{\mathrm{a}}$ & $18.51^{\mathrm{a}}$ & $19.84^{\mathrm{a}}$ \\
\hline Control & $15.63^{\mathrm{c}}$ & $15.76^{\mathrm{e}}$ & $18.24^{\mathrm{d}}$ \\
\hline F-test & $* *$ & $* *$ & $* *$ \\
\hline LSD (0.05) & 0.40 & 0.24 & 0.09 \\
\hline $\operatorname{SEm}( \pm)$ & 0.12 & 0.08 & 0.03 \\
\hline $\mathrm{CV}, \%$ & 1.43 & 0.90 & 0.31 \\
\hline Grand Mean & 16.49 & 17.32 & 19.24 \\
\hline
\end{tabular}

\section{Economic analysis}

Economic analysis of data (Table 10) revealed that significantly maximum gross return (NRs. 2076.13 thousands/ha) and net return (NRs. 1683.13 thousands/ha) were obtained in perforated black plastic mulch which were statistically at par with white plastic and silver plastic mulch. The minimum gross return and net profit were obtained in control plot. The highest B:C ratio was obtained in perforated black plastic mulch (5.83) which was statistically at par with silver plastic (5.44) and white plastic (5.29). These were followed by black plastic mulch (4.97) and control plot (4.24).

Table 10: Economics of potato production as influenced by plastic mulches at Dadeldhura, Nepal in 2020.

\begin{tabular}{|c|c|c|c|c|}
\hline Treatments & $\begin{array}{c}\text { Total Cost of } \\
\text { Cultivation (NRs.) }\end{array}$ & $\begin{array}{l}\text { Gross } \\
\text { Return } \\
\text { (NRs.) }\end{array}$ & $\begin{array}{l}\text { Net } \\
\text { Return } \\
\text { (NRs.) }\end{array}$ & B:C Ratio \\
\hline White plastic & 393000 & $2076130^{\mathrm{ab}}$ & $1683130^{\mathrm{ab}}$ & $5.29^{\mathrm{ab}}$ \\
\hline Silver plastic & 393000 & $2136360^{\mathrm{ab}}$ & $1743360^{\mathrm{ab}}$ & $5.44^{\mathrm{ab}}$ \\
\hline Perforated black plastic & 394400 & $2298715^{\mathrm{a}}$ & $1904315^{\mathrm{a}}$ & $5.83^{\mathrm{a}}$ \\
\hline Black plastic & 393000 & $1952250^{\mathrm{b}}$ & $1559250^{\mathrm{b}}$ & $4.97^{\mathrm{bc}}$ \\
\hline Control & 365000 & $1546600^{\mathrm{c}}$ & $1181600^{c}$ & $4.24^{\mathrm{c}}$ \\
\hline F-test & - & $* *$ & $* *$ & $* *$ \\
\hline $\operatorname{LSD}(0.05)$ & - & 308442.50 & 308442.50 & 0.78 \\
\hline $\operatorname{SEm}( \pm)$ & - & 100101.20 & 100101.20 & 0.25 \\
\hline $\mathrm{CV}, \%$ & - & 10.00 & 12.40 & 9.89 \\
\hline Grand Mean & 387680 & 2002011 & 1614331 & 5.15 \\
\hline \multicolumn{5}{|c|}{$\begin{array}{l}\text { Means followed by the same letter(s) in a column are not significantly different by DMRT at } 5 \% \text { level of } \\
\text { significance. } n s=\text { Non-significant, } *=\text { significant at } 5 \% \text { probability level, } * *=\text { significant at } 1 \% \text { probability } \\
\text { level, } \\
\text { NRs. }=\text { Nepali Rupees, Local market price of potato }=N R s .38 / \mathrm{kg}\end{array}$} \\
\hline
\end{tabular}

\section{CONCLUSION}

Based on the result of this experiment, it would be better to use perforated black plastic mulch for optimum growth and yield of potato production in agro-climatic conditions of Dadeldhura. Furthermore, it is suggested to conduct multi-location and multi-seasonal trials on this aspect to achieve more accurate results. 
Journal of Agriculture and Natural Resources (2020) 3(2): 228-240

ISSN: 2661-6270 (Print), ISSN: 2661-6289 (Online)

DOI: https://doi.org/10.3126/janr.v3i2.32509

\section{ACKNOWLEDGEMENTS}

Authors want to acknowledge Agriculture and Forestry University, Rampur Chitwan and Prime Minister Agriculture Modernization Project (PMAMP) for funding and providing platform for the research.

\section{Authors' Contributions}

M. Bhatta designed the research plan, conducted experiment and prepared manuscript. B. Shrestha, A. R. Devkota, K. R. Joshi, S. Bhattarai and U. Dhakal helped for conduciton the experiment, data recording and preparing this manuscript.

\section{Conflict of Interest}

The authors declare that there are no conflicts of interest regarding publication of this manuscript.

\section{REFERENCES}

Ahmed, N. U., Mahmud, N. U., Hossain, A., Zaman, A. U., \& Halder, S. C. (2017). Performance of mulching on the yield and quality of potato. International Journal of Natural and Social Sciences, 4(2), 07-13.

Azad, B. H. (2015). Effect of mulch on some characteristics of potato in Asadabad, Hamedan. International Journal of Agronomy and Agricultural Research (IJAAR), 6, 139-147.

Bharati, S., Joshi, B., Dhakal, R., Paneru, S., Dhakal, S., \& Joshi, K. (2020). Effect of Different Mulching on Yield and Yield Attributes of Potato in Dadeldhura, Nepal. Malaysian Journal of Sustinable Agriculture (MJSA), 4(2), 54-58.

DOI: https://dx.doi.org/10.26832/24566632.2019.040109

FAO. (2018). FAO STAT. Food and Agriculture Organization.

Gairhe, S., Gauchan, D., \& Timsina, K. (2017, May). Adoption of Improved Potato Varieties in Nepal. (R. R. Gokul P. Paudel, Ed.) Journal of Nepal Agricultural Research Council, 3, 38-44. doi: https://doi.org/10.3126/jnarc.v3i1.17274

Gomez, K., \& Gomez, A. (1984). Statistical procedures for agricultural research (2 ed.). International Rice Research Institute, College, Laguna.

Hatfield, J. L. (2001). Managing soils to achieve greater water use efficiency. Agronomy Journal, 63(12), 1056-1057.

Hochmuth, G. H. (2018). Polyethene mulching for Early Vegetable Production in North Florida. 1-6. Retrieved from http://edis.ifas.ufl.edu.

Hundal, I. S., Sandhu, K. S., Daljeet, S., \& Sandha, M. S. (2000). Effects of different types of mulching and herbicidal treatments on nutrient uptake in tomato (Lycopersicon esculentum). Haryana Journal of Horticultural Sciences, 29(3-4), 242-244.

Joshi , B., Dhakal , R., Bharati, S., Dhakal , S., \& Joshi , K. (2020). Effect of Planting Depth and Mulching Materials on Yield and Yield Attributes of Potato in Dadeldhura, Nepal. Agriculture, Forestry and Fisheries, 9(3), 45-53.

Kadar, M., Senge, M., Mojid, M., \& Onishi, T. (2017). Effects of plastic-hole mulching on effective rainfall and readily available soil moisture under soybean (Glycine max) cultivation. Paddy and Water Environment. doi:10.1007/s10333-017-0585-z

Kang, B. K., Kang, Y. K., \& Kang, S. Y. (2003). Influence of Polyethylene Film Mulch and Seedling Types on Growth and TuberYield of Fall-Grown Potato. Korean Journal of Crop Science. 
Journal of Agriculture and Natural Resources (2020) 3(2): 228-240

ISSN: 2661-6270 (Print), ISSN: 2661-6289 (Online)

DOI: https://doi.org/10.3126/janr.v3i2.32509

Kapoor, P. R. (2012). Effect of polythene mulches and barrier crops on virus disease incidence and yield of ell pepper. Indian Phytopathology, 65(4), 391-394.

Khan, A., Jilani, M., Khan, M., \& Zubair, M. (2011). Effect of Seasonal Variation on Tuber Bulking Rate of Potato. The Journal of Animal \& Plant Sciences, 21(1), 31-37.

Kumari, S. (2012). Influence of drip irrigation and mulch on leaf area maximization, water use efficiency and yield of potato (Solanum tuberosum L.). Journal of Agricultural Science, 4(1), 79-86.

Luis, J., Hugo, L., Luis, A., \& Lozano, D. R. (2011). Colored plastic mulches affect soil temperature and tuber production of potato. Acta Agriculturae Scandinavica, Section B-Soil \& Plant Science, 61(4), 365-371.

Mahmood, M. M., Farooq, K., Hussain, A., \& Sher, R. (2002). Effect of Mulching on Growth and Yield of Potato Crop. Asian Journal of Plant Sciences, 1, 132-133. doi: 10.3923/ajps.2002.132.133

Manganelli, C. C. (2017). Coloured Plastic Mulches Improve the Growth and Yield of the 'Micro-Tom' Tomato in High-Density Plantings. São Paulo State: College of Agricultural and Veterinary Sciences.

Matheny, T. H. (1992). Potato Tuber Production in Response to Reflected Light from Different Coloured Mulches. Crop Science Society of America. doi: https://doi.org/10.2135/cropsci1992.0011183X003200040037x

Memon, M. S., Jun, z., Jun, G., Ullah, F., Hassan, M., Ara, S., \& Changying, J. (2017). Comprehensive review for the effects of ridge furrow plastic mulching on crop yield and water use efficiency under different crops. International Agricultural Engineering Journal, 26, 58-67.

MoALD. (2018/19). Statistical Information on Nepalese Agriculture 2075/76 (2018/19). Kathmandu: Government of Nepal.

NRCS, U. (2012). Mulching Principles and Calculations. PACIFIC ISLANDS: Natural Resources Conservation Service, USDA.

Orzolek, M. D., Murphy, J., \& Ciardi, J. (1993). The effect of coloured polyethylene mulch on the yield of squash,tomato and cauliflower. Final Report to the Pennsylvania Vegetable Marketing and Reaserach Commodity Board, The Pennsylvania State University, USA.

Ping, H. C., Xuejun, Y. E., \& Xing, C. J. (1994). The physiological and ecological effects of covering plastic film on potato. Acta Agriculture zhejiangensis, 6, 102-106.

Reddy, B. J., Mandal, R., Chakroborty, L., Hijam, L., \& Dutta, P. (2018). A Review on Potato (Solanum tuberosum L.) and its Genetic Diversity. International Journal of Genetics, $1 o(2), 360-364$.

Samy, M. M., \& EI-Zohiri, S. (2013). Influence of Colored Plastic Mulches and Harvest Date on Tubers Yield, and Quality, of Potato. Journal of Applied Sciences, 28(12B), 845859.

Shrestha, J. (2019). P-Value: A True Test of Significance in Agricultural Research, https://www.linkedin.com/pulse/p-value-test-significance-agricultural-research-jibanshrestha/ . DOI: http://doi.org/10.5281/zenodo.4030711

Singh, N., \& Ahmed, Z. (2008). Effect of Mulching on Potato Production in High Altitude Cold Arid. Potato Journal, 35(3-4), 118-121.

Subedi, S., Ghimire, Y.N., Gautam, S., Poudel, H.K., \& Shrestha, J. (2019). Economics of potato (Solanum tuberosum L.) production in terai region of Nepal. Archives of Agriculture and Environmental Science, 4(1), 57-62. 
Journal of Agriculture and Natural Resources (2020) 3(2): 228-240

ISSN: 2661-6270 (Print), ISSN: 2661-6289 (Online)

DOI: https://doi.org/10.3126/janr.v3i2.32509

Upadhyay, K.P., Dhami, N.B., Sharma, P.N., Neupane, J.D., \& Shrestha, J. (2020a). Growth and yield responses of potato (Solanum tuberosum L.) to biochar. Agrarian Science, 31 (2): In Press. doi: 10.15159/jas.20.18. 